\title{
ХӨХ ХОТ ОРЧМЫН ТАРИАН ТАЛБАЙН ШУВУУДЫН БУЛГЭМДЛИЙН УЛИРЛЫН БОЛОН ӨДРИЙН ИДЭВХЖИЛИЙН СУДАЛГАА
}

\author{
Г.Ариунжаргал, Yang Gui-sheng, Wu Ri Han \\ Өвөр монголын их сургууль \\ E-mail: ariunaa1982@yahoo.com
}

\section{ХУРААНГУЙ}

Судалгааг 2011 оны 1-p сараас 12 сар хүртэлх хугащаанд хийлээ. ЭнэхүY өгүүллэгээр иэгэн трансектийн судалгааны аргийг ашиглан Хөх хотын зүҮн хэсгийн тариалангийн талбайн шувуудын бүлгэмдлийн өдрийн болон улирлын идэвхийн судалгааны үр дүнг танилиуулж байна. Судалгаань хугащаанд нийт 8 баг, 19 овог, 31 зүйлийн 13867 бодгаль тэлдэглэсэн. Судалгаанаас харахад 1-р сараас 8-р сар хүртэл шувуудын бүлгэмдлийн идэвхжсил харьияангуй тогтвортой байснаа 9-р сараас эрс өссөөр 11-р сард оргил үедээ хүрээд 12-р сараас эхлэн эргэн буурч 1-р сараас эргэн тогтворжсон үр дүнтэй байлаа. Шувуудын идэвхэилийн оргил үе нь 1, 2, 3 дугаар саруудад 8:00--10:00 ичагийн хооронд, 4, 6, 7, 8, 11 дүгээр саруудад 6:00--8:00 иагийн хооронд, 5, 10 дугаар сард 16:00--18:00 цагийн хооронд, 9-р сард 14:00--16:00, 12-р сард 10:00--12:00 ияагийн хооронд тус тус таарч байна. Шувуудын бүлгэмдлийн идэвхжилийн оргил үе улирльн өөрчлөлтөөс хамаарч харилиан адилгүй хугачаанд тохиолддог нь харагдлаа.

ТУЛХУУР ҮГ: Шувуу, идэвхжил, Хөх хот

\section{ОРШИЛ}

Жигүүртний аймаг нь байгалийн экосистемд тэргүүлэх үүрэг гүйцэтгэхээс гадна хүний гараар бүтээсэн агроценозод ч асар их үүрэгтэй. Хүн төрөлхтний хөгжил дэвшил, нийгэмших үйл явцад хот суурин байгуулах, газар тариалан эрхлэх гэх мэтээр жигүүртний аймгийн амьдрах орчин амьдралын хэлбэрт олон талаар нөлөөлөх болсон.

Үүнтэй холбоотойгоор хүнд ойромсог буюу синантроп зүйлүүд олширсон. Энэ нь эргээд хог хаягдал үүсгэх, элдэв халдварт өвчин тараaх, онгоц мөргөлдөх гэх мэт олон сөрөг үр дагавар авчрах болжээ. Иймд жигүүртний аймгийн биологи, экологийн судалгааг нарийвчлан хийх нь чухал ач холбогдолтой. Энэхүү өгүүллэгт Хөх хотын “Байта" онгоцны буудлын дэргэдэх тариалангийн талбайн шувуудын бүлгэмдлийн өдрийн болон улирлын идэвхийн судалгааны үр дүн танилцуулна. 


\section{СУДАЛГААНЫ МАТЕРИАЛ, АРГА ЗУЙ}

Цэгэн судалгааны арга: Бид судалгаа хийсэн нутгийн байгалийн нөхцөл, шувууны аймгийн төлөв байдлыг тодруулахдаa цэгэн болон шугаман маршрутын аргыг ашиглав /энэ өгүүлэлд зөвхөн цэгэн трансектийн аргаар цуглуулсан материалыг нэгтгэсэн болно/. Хээрийн судалгааг цаг агаарын тохиромжтой нөхцөлд, шувуудын идэвхитэй цагуудад хийж гүйцэтгэсэн. Цэгэн трансектийн судалгааг 2 цэгт, сард 3 удаа тухайн сонгон авсан цэгээс 150 м радиус дотор хийлээ. Нэг удаагийн ажиглалтыг 2 цагийн зайтай 10 минут хийж, ажиглагдсан шувуудын зүйл, тоо толгой, идэвхи болон тухайн үеийн цаг агаарын нөхцөлийг тэмдэглэв. Хээрийн ажиглалтанд 20-60 өсгөлттэй, 45 ммийн дуран ашиглав.

Судалгааны талбай: Хээрийн судалгааг эрдэнэ шишийн тариалангийн талбай дээр 2 цэгт хийсэн. Энд мөн төмс, шар буурцаг бага хэмжээгээр тариалдаг. Цэгэн трансектийн аргаар 150 м радиуст ажиглалт хийсэн бөгөөд

\section{СУДАЛГААНЫ ҮР ДУН}

Тариан талбайн шувуудын бүрдэл: Судалгааны хугацаанд нийт 8 баг, 19 овог, 31 зүйлийн 13867 бодгаль тэмдэглэсэн. Нийт тэмдэглэгдсэн шувуудын 16 зүйл буюу 52\% суурин (R), 11 зүйл буюу 35\% өндөглөн зусдаг $(\mathrm{S}), 3$ зүйл буюу $10 \%$ өвөл ирдэг (W), 1 зүйл $3 \%$ дайран өнгөрдөг (Р) байна (Zhang 1999; Гомбобаатар нар 2011). Зэрлэг амьтан ургамлын ховордсон зүйлийг олон улсын хэмжээнд худалдаалах тухай конвенцийн (CITES) II хавсралтанд шууман шонхор Falco subbuteo, начин шонхор Falco tinnunculus, шилийн сар Buteo hemilasius орсон байдаг (Zheng 2005; Болд нар 2007) .

Тариан талбайн шувуудын өдрийн идэвхжил: Бид шувуудын улирлын болон өдрийн судалгааны талбайг $S=\pi r^{2}$ томьёогоор тооцож гаргав. Судалгааны талбай тус бүр $70650 \mathrm{~m}^{2}$ буюу 7.065 га. Судалгааны нийт талбай $S=14.13$ га.

\section{Статистик боловсруулалт:}

$\checkmark$ Нягтшилыг D = N/S томъёогоор олов. Энд D шувуудын нягтшил; $\mathrm{N}$ тэмдэглэгдсэн шувуудын тоо, S судалгааны талбай (га-р). Судалгааны үр дүнг Excel программ ашиглан боловсруулсан.

Хээрийн ажиглалтын хугацаа: Хээрийн судалгааг 2011 оны 1-р сараaс 2011 оны 12-р сарын хооронд хугацаанд гүйцэтгэв. Бид шувуудын улирлын идэвхжилийг сараар, харин өдрийн идэвхжилийг цагаар тооцож гаргасан. Үүнд: Улирлыг өвөл XI.11-III.20, хавар III.21V.20, зун V.21-VIII.15, намар VIII.16-XI.10 гэж тооцсон болно(Yang 2007).

идэхжилийг тодорхойлохдоо 100-аaс дээш тоогоор тохиолдсон 9 зүйлийн (Corvus dauuricus5290, Passer montanus-4037, Pica pica-1672, Streptopelia decaocto-905, Columba livia-601, Corvus frugilegus-390, Emberiza pusilla-177, Hirundo rustica-158, Corvus corone-168) тоон мэдээнд тулгуурлан хийв.

Энэ 9 зүйл шувуу тухайн бүлгэмдлийн зүйлийн $29.03 \%$-ыг эзлэх боловч тухайн бүлгэмдэлд тэмдэглэгдсэн нийт бодгалийн 96.61\% (13398) эзэлж байна. Өөрөөр хэлбэл энэхүу 9 зүйл шувуудын тохиолдсон тоогоор тухайн бүлгэмдлийн шувуудын өдрийн болон улирлын идэвхийг бүрэн тодорхойлох боломжтой. Эдгээр шувуудын 7 зүйл суурин (R), 2 зүйл нүүдлийн (S) шувууд байна.

Шувуудын бүлгэмдлийн улирлын идэвхжил 
Хүснэгт 1

Хамгийн олон тоогоор тохиолдсон 9 зүйл шувуу

/тохиолдсон тоо, улирлаар/

\begin{tabular}{|c|c|c|c|c|c|c|c|c|c|c|c|}
\hline $\begin{array}{c}\text { Зүйлийн } \\
\text { нэр/ улирал }\end{array}$ & 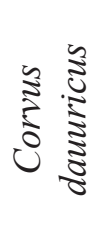 & 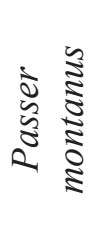 & 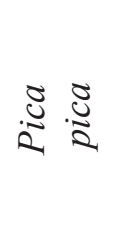 & 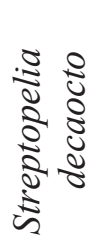 & 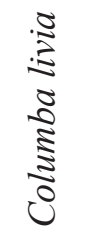 & 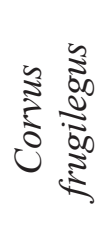 & 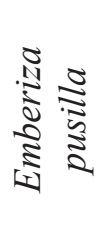 & 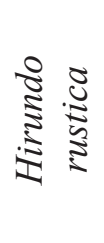 & 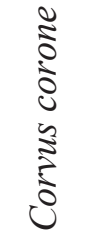 & Нийт & $\begin{array}{c}\text { Улирлын } \\
\text { нягтшил } \\
\text { /га-р/ }\end{array}$ \\
\hline Намар & 1180 & 2068 & 374 & 433 & 146 & 64 & 64 & 53 & 122 & 4504 & 7.37 \\
\hline Өвөл & 4059 & 1062 & 829 & 182 & 200 & 155 & 0 & 0 & 29 & 6516 & 10.67 \\
\hline Хавар & 47 & 320 & 255 & 49 & 129 & 131 & 111 & 3 & 17 & 1062 & 1.73 \\
\hline Зун & 4 & 587 & 214 & 241 & 126 & 40 & 2 & 102 & 0 & 1316 & 2.15 \\
\hline Нийт & 5290 & 4037 & 1672 & 905 & 601 & 390 & 177 & 158 & 168 & 13398 & 5.48 \\
\hline $\begin{array}{l}\text { Зүйлийн } \\
\text { нягтшил }\end{array}$ & 8.66 & 6.61 & 2.73 & 1.48 & 0.98 & 0.63 & 0.28 & 0.25 & 0.27 & - & - \\
\hline
\end{tabular}

Гуравдугаар хүснэгтээс үзэхэд өвлийн улиралд нэг км² талбайд хамгийн олон шувуу буюу 10.67 , намар 7.37, харин хавар, зун цөөн буюу 1.732.15 бодгаль тохиолдох нягтшилтэй байна. Харин шувуудын нягтшилыг зүйлээр авч үзвэл Corvus dauuricus-8.66, Passer montanus-6.61 хамгийн их байлаа.

Сонгон авсан 9 зүйл шувууны сар тутам тэмдэглэгдсэн нийт тоог дараах тахирмагаар харуулав.

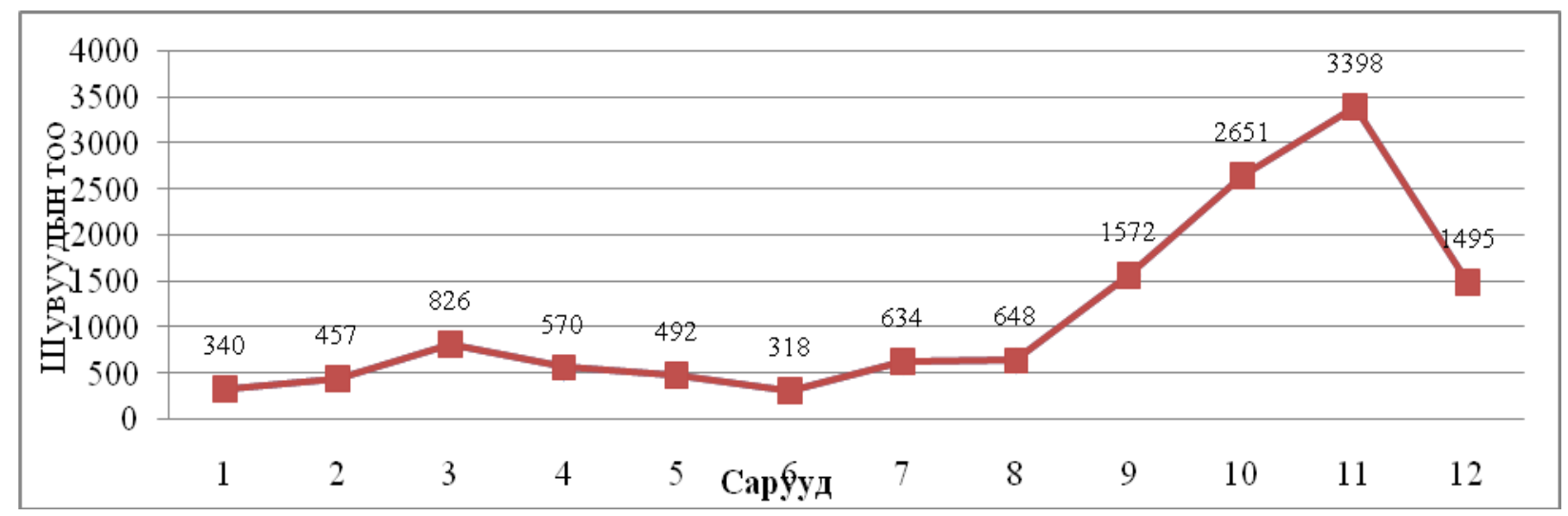

1-р зураг. Үндсэн 9 зүйл шувууны тоологдсон тоо /сараар/

Зураг дээрх тахирмагаас харахад 1-р сараас 8-p cap хүртэл шувуудын бүлгэмдлийн идэвхжил харьцангуй тогтвортой байснаа 9-р сараас эрс өссөөр 11-р сард оргил үедээ хүрээд 12-р сараас эхлэн эргэн буурч 1-р сараас эргэн тогтворжсон үр дүн харагдаж байна.

Corvus dauuricus, Passer montanus 2 зүйл шувууны тоо 1-p сараaс 8-p сар хүртэл харьцангуй тогтвортой байжээ. Харин Corvus dauuricus 9-р сараас эхлэн тоо толгой огцом өсч 11-р сард оргил үедээ (2709) хүрээд 12-р сараас эргэн буурсан үзүүлэлт ажиглагдав. Passer montanus тоо толгой 10-р сард оргил (1350) үедээ хүрч 11-p сараас эргэн буурчээ. Тухайн бүлгэмдлийн идэвхжилд голлох нөлөө үзүүлдэг шувуу Passer montanus, Corvus dauuricus байна.

Шувуудын бүлгэмдлийн өдрийн идэвхжил улирлаар: Бид хээрийн судалгааны хугацаанд цугласан тоон мэдээн дээрээ үндэслэн тухайн бүлгэмдлийн шувуудын өдрийн идэвхжилийг улирал тус бүрээр гаргалаа. 
Хөх хотын тариан талбайн шувуудын өдрийн идэвхжил /сараар/

Хүснэгт 2

\begin{tabular}{clccccccc}
\hline Сар & Цаг & $6--8$ & $8--10$ & $10--12$ & $12--14$ & $14--16$ & $16--18$ & $18--20$ \\
\hline \multirow{2}{*}{1} & Зүйлийн тоо & 0 & 5 & 5 & 5 & 3 & 3 & 0 \\
& Тоологдсон тоо & 0 & 216 & 179 & 33 & 47 & 44 & 0 \\
2 & Зүйлийн тоо & 1 & 6 & 5 & 4 & 4 & 5 & 0 \\
& Тоологдсон тоо & 1 & 217 & 40 & 81 & 49 & 69 & 0 \\
\multirow{2}{*}{3} & Зүйлийн тоо & 4 & 7 & 6 & 4 & 3 & 6 & 5 \\
& Тоологдсон тоо & 155 & 202 & 85 & 107 & 58 & 43 & 167 \\
\multirow{2}{*}{4} & Зүйлийн тоо & 6 & 7 & 5 & 5 & 4 & 6 & 5 \\
& Тоологдсон тоо & 153 & 113 & 76 & 30 & 38 & 125 & 34 \\
\multirow{2}{*}{5} & Зүйлийн тоо & 6 & 6 & 7 & 7 & 6 & 8 & 7 \\
& Тоологдсон тоо & 73 & 100 & 63 & 47 & 42 & 105 & 93 \\
\multirow{2}{*}{6} & Зүйлийн тоо & 5 & 5 & 6 & 2 & 5 & 6 & 5 \\
& Тоологдсон тоо & 87 & 49 & 21 & 11 & 44 & 46 & 60 \\
7 & Зүйлийн тоо & 5 & 4 & 5 & 3 & 5 & 5 & 5 \\
& Тоологдсон тоо & 242 & 50 & 71 & 42 & 66 & 71 & 92 \\
8 & Зүйлийн тоо & 6 & 4 & 4 & 4 & 4 & 5 & 5 \\
& Тоологдсон тоо & 238 & 133 & 66 & 56 & 58 & 44 & 53 \\
\multirow{2}{*}{9} & Зүйлийн тоо & 9 & 7 & 5 & 4 & 8 & 5 & 7 \\
& Тоологдсон тоо & 221 & 138 & 247 & 106 & 604 & 120 & 136 \\
10 & Зүйлийн тоо & 7 & 6 & 7 & 4 & 4 & 4 & 4 \\
& Тоологдсон тоо & 413 & 423 & 530 & 160 & 440 & 611 & 64 \\
\multirow{2}{*}{11} & Зүйлийн тоо & 4 & 5 & 6 & 5 & 5 & 4 & 1 \\
& Тоологдсон тоо & 1087 & 828 & 270 & 389 & 533 & 292 & 3 \\
\multirow{2}{*}{12} & Зүйлийн тоо & 0 & 0 & 5 & 5 & 4 & 3 & 4 \\
& Тоологдсон тоо & 0 & 0 & 555 & 226 & 162 & 237 & 118 \\
\hline \multirow{2}{*}{} & & & & & & & &
\end{tabular}

Шувуудын бүлгэмдлийн өдрийн идэвхжлийн оргил цагууд

Хүснэгт 3

\begin{tabular}{|c|c|c|c|}
\hline Cap & Шувуудын зүйлүүд & $\begin{array}{c}\text { Оргил } \\
\text { цаг }\end{array}$ & Давамгайлагч зүйл \\
\hline 1 & $\begin{array}{l}\text { Corvus dauuricus, Passer montanus, Pica pica, } \\
\text { Streptopelia decaocto, Columba livia }\end{array}$ & $08--10$ & $\begin{array}{l}\text { Passer montanus } \\
(48.14 \%)\end{array}$ \\
\hline 2 & $\begin{array}{l}\text { Corvus dauuricus, Passer montanus, Pica pica, } \\
\text { Streptopelia decaocto, Columba livia, Corvus corone }\end{array}$ & 08--10 & $\begin{array}{l}\text { Passer montanus } \\
(31.29 \%)\end{array}$ \\
\hline 3 & $\begin{array}{l}\text { Corvus daunricus, Passer montanus, Pica pica, } \\
\text { Streptopelia decaocto, Columba livia, Corvus } \\
\text { frugilegus, Corvus corone }\end{array}$ & $08--10$ & $\begin{array}{l}\text { Passer montanus } \\
(33.66 \%)\end{array}$ \\
\hline 4 & $\begin{array}{l}\text { Corvus dauuricus, Passer montanus, Pica pica, } \\
\text { Streptopelia decaocto, Columba livia, Corvus } \\
\text { frugilegus, Corvus corone }\end{array}$ & $06--08$ & $\begin{array}{l}\text { Columba livia, } \\
(35.94 \%)\end{array}$ \\
\hline 5 & $\begin{array}{l}\text { Corvus dauuricus, Passer montanus, Pica pica, } \\
\text { Streptopelia decaocto, Columba livia, Corvus frugilegus, } \\
\text { Emberiza pusilla,Hirundo rustica, }\end{array}$ & $16--18$ & $\begin{array}{l}\text { Emberiza pusilla } \\
(37.14 \%)\end{array}$ \\
\hline 6 & $\begin{array}{l}\text { Corvus dauuricus, Passer montanus, Pica pica, } \\
\text { Streptopelia decaocto, Corvus frugilegus }\end{array}$ & $06--08$ & $\begin{array}{l}\text { Passer } \\
\text { montanus }(36.78 \%), \\
\text { Pica pica }(36.78 \%)\end{array}$ \\
\hline 7 & $\begin{array}{l}\text { Passer montanus, Pica pica, Streptopelia decaocto, } \\
\text { Columba livia, Hirundo rustica }\end{array}$ & $06--08$ & $\begin{array}{l}\text { Hirundo rustica } \\
(31.81 \%)\end{array}$ \\
\hline 8 & $\begin{array}{l}\text { Passer montanus, Pica pica, Streptopelia decaocto, } \\
\text { Columba livia, Corvus frugilegus, Hirundo rustica, }\end{array}$ & $06--08$ & $\begin{array}{l}\text { Passer montanus } \\
(49,57 \%)\end{array}$ \\
\hline
\end{tabular}



Corvus dauuricus, Passer montanus, Pica pica,
$14--16$
Corvus dauuricus
Streptopelia decaocto, Columba livia, Corvus frugilegus,
Emberiza pusilla, Corvus corone
Corvus dauuricus, Passer montanus, Pica pica,
10
Streptopelia decaocto
(31.45\%), Passer
montanus (41.22\%),
16--18 Corvus dauuricus
(47.95\%), Passer
montanus (45.66\%),
11 Corvus dauuricus, Passer montanus, Pica pica,
Streptopelia decaocto
12
Corvus dauuricus, Passer montanus, Pica pica,
Streptopelia decaocto, Columba livia,
06--08 Corvus dauuricus
$(95.76 \%)$,
10--12 Corvus daunicus
$(60.00 \%)$,

Тайлбар: Тухайн сарын шувуудын бүлгэмдлийн оргил цаг, тухайн цагт нийт тохиолдсон зүйлүүд, 30иас дээш хувиар тохиолдсон зүйлүүд

Шувуудын бүлгэмдлийн улирлын идэвхжилийг улирлаар авч үзвэл оргил үе нь 1, 2, 3 дугаар саруудад 8:00--10:00 цагийн хооронд, $4,6,7,8$, 11 дүгээр саруудад 6:00--8:00 цагийн хооронд, 5,
10 дугаар сард 16:00--18:00 цагийн хооронд, 9-р сард 14:00--16:00, 12-р сард 10:00--12:00 цагийн хооронд тус тус тохиож байна.

\section{ШУУН ХЭЛЭЛЦЭХУЙ}

Харилцан адилгүй саруудад шувуудын тоологдсон тоо болон оргил үе харилцан адилгүй. Энэ нь нарны тусгал, температур гэх мэт орчны хүчин зүйлүүдийн өөрчлөлттэй хамаатай.

Тунлиа хотод хийсэн ижил төсөөтэй судалгаанаас үзвэл 1, 2 болон 12 сард шувуудын өдрийн идэвхжлийн оргил үе нь 8:00--10:00 цагт, 3, 10 сард 8:00--10:00, 14:00--16:00 цагт, 4, 5 сард 8:00--12:00 цагт, 6, 7 сард 16:00--18:00 цагт, 8, 9 сард 6:00--8:00 цагт, 11 сард 6:00--10:00 цагт байжээ (Chen Не нар 2010 ).

Зуны улиралд тариалангийн талбайн шувуудын бүлгэмдэл тогтвортой байна. Энэ үед шавж болон тэдгээрийн өт авгалдай түргэн өсөж үрждэг тул тэдгээрээр хооллодог шувууд тариан талбай дээр тохиолдоно. Зун үдэд температур өндөр байдаг болохоор шувуудын идэвхи бага харин эрт болон оройн сэрүү унахад оргил үе нь таардаг. Намар температур буурч эхэлдэг ч шувуудын тоологдсон тоо өглөө эрт илүү олон байна. Тариалангийн талбайд унасан ургамлын үр жимс, үлдэгдэл, ургац хураах үед хөрсөн дээр ил гарсан шавж зэргээр хооллохоор шувууд сүрэг үүсгэн ойр зуур нүүдэллэн явдаг. Мөн шинэ залуу шувууд олноор сүрэгт нэмэгдсэнээр шувуудын зүйлийн болон бодгалийн тоо зуны улирлынхаас эрс ихсэнэ (Aryuna 2012; Wu нар 2011).

Өвөл өдөр богино, цаг агаар хүйтэн шувуудын оргил үе нь 10:00--12:00 цагийн хооронд, 1-p сард цаг агаар маш хүйтэн, шувуудын тоологдсон тоо оргил үе нь 10:00--12:00 цагийн хооронд байна. Өвлийн улиралд тариан талбайд цөөн зүйлийн шувууд олон тоогоор бөөгнөрөн цасны нимгэнийг даган хоол тэжээл хайн өвөлждөг.

Хавар тариалангийн талбайг хагалан, тариалалт эхлэх үеээс хөрсний үе хөлтөн, шоргоолж, шавж, ялаа, шумуул, ургамлын шинэ навч, нялх соёо, цоморлиг, мөн хог хаягдал зэрэг шувуудын гол хоол хүнс элбэг болно. Үүнтэй зэрэгцэн шувуудын зүйлийн тоо нэмэгддэг.

Намар нүүдлийн оргил үе тул тоологдсон тоо нь их байна. Өвлийн эхэнд хүйтэрч шувуудын тоо тогтворжих хандлагатай болж эхлэх ба шувууд сүрэг үүсгэнэ. Гол сүрэг үүсгэн явдаг шувуу нь Corvus dauuricus, Passer montanus, Pica pica, Streptopelia decaocto, Columba livia, Corvus frugilegus, Corvus corone болно. Энэхүу үр дүн нь бидний судалгаагаар батлагдаж байна.

\section{ДУГНЭЛТ}

1. Тухайн нутгийн шувуудын бүлгэмдлийн гол цөмийг суурин (R) болон өндөглөн зусдаг (S) шувууд $/ 27$ зүйл шувуу буюу нийт зүйлийн 87\%-ийг/ бүрдүүлж байна.

2. Шувуудын бүлгэмдлийн улирлын идэвхжилийг улирлаар авч үзвэл оргил үе нь 1 , 2, 3 дугаар саруудад 08--10 цагийн хооронд, 4, $6,7,8,11$ дүгээр сард 06--08 цагийн хооронд, 
5, 10 дугаар сард 16--18 цагийн хооронд, 9-р сард 14--16, 12-р сард 10--12 цагийн хооронд тус тус таарч байна.

\section{АШИГЛАСАН МАТЕРИАЛ}

1. Yang Guisheng, Lixin, 2007. Study on Avian diversity and community structure in Spring of White Tower Airport in Hohhot [J]. Journal of Inner Mongolia University. Hohhot 38(4):38-42.

2. Zhang Rongzu. 1999. Animal Geography of China [M]. Beejin: Science Press.

3. С. Гомбобаатар ба бусад. 2011. Монгол орны шувуудын улаан данс.

4. Zheng Guangmei Bird taxonomy and distribution list of China [M]. Beejin: Science Press. 2005, 98-101.

5. А.Болд, Н.Цэвээнмядаг, Ш.Болдбаатар, Г.Майнжаргал, 2007. Монгол орны шувууны зүйлийн нэрийн арван хэлний толь. Төрийн хэлний зөвлөл, Шинжлэх ухааны академи, Хэл зохиолын хүрээлэн, Хэрэглээний хэл
3. Шувуудын бүлгэмдлийн идэвхжил 9-р сараас эрс өсөж эхлэх ба 11-р сард хамгийн өндөр төвшинд хүрч байна.

шинжлэлийн сектор, Биологийн хүрээлэн шувуу судлалын лаборатори. X-4.

6. Chen He, Yang Yong, Zhang Shifeng, Xu Ying, Zhang Le, Yang Guisheng , 2010. A Study on Daily Activity Rhythm of Birds and the Avoidance of Birdstrike in Tongliao Civil Aviation Airport . Zoological Research 41(3):331-335.

7. Aryuna Norboeva, 2012. Seasonal dynamics of bird community structure in Hohhot. College of Life Sciences, Inner Mongolia University, Master thesis 24-28.

8. Wu Shu Nan, Yang Gui-sheng, 2011. Differences and Analysis of Avifauna Composition at Civil Airports in Inner Mongolia [J]. Journal of Inner Mongolia University, Hohhot 42(4):428-441.

\title{
BIRDS COMMUNITY STRUCTURE AND ACTIVITY RHYTHM IN HOHHOT FARMLAND
}

\section{G.Ariunjargal, Yang Gui-sheng, Wu Ri Han}

\author{
College of Life Sciences, Inner Mongolia University
}

E-mail; ariunaa1982@yahoo.com

The investigation was conducted from January, 2011 till December 2011. In this paper, we discussed the result of daily and seasonal activity investigation for the eastern Hohhot farmland birds community, determined with transect method and fixed-radius point count method. For the investigation period, a total of 13867 individuals, belonging to 31 bird species, 8 orders and 19 families, were recorded. Study suggests that from January to August bird community activity was relatively stable, but increased dramatically from September till reaching its peak in November, falling back from December till in January to show stable results back. The daily and seasonal activity peaks of birds were observed, between 8.00--10:00 am from January till March, between 6:00--8:00 am in April, June, July, August and November, between 2-4 pm in May and October, and between 10:00--12:00pm in September and December. Bird community activity peak varies with seasonal changes. 